\title{
At the fabric of history: Peru's political struggle under (and against) the pandemic
}

\author{
Mijail Mitrovic ${ }^{1}$ (D)
}

Published online: 30 December 2021

(c) The Author(s), under exclusive licence to Springer Nature B.V. 2021

I finished writing this essay in mid-July 2021. Although the current situation deserves to be analysed on its own terms, I have opted to keep the text as it was completed. At the time, Pedro Castillo's proclamation had been postponed by the dirty tricks of the losing side, and we did not yet know the first steps of the new government and the opposition. I deal with this briefly in the last section, written between August and October.

If by mid-2020, it was almost a consensus that the pandemic in Peru had revealed the structural inequality concealed behind the triumphalism of the "Peruvian miracle" from the dictatorship of the 1990s until well into the new millennium, we could say that the succession of critical junctures between November and the present oblige us to go beyond that nuanced recognition of the weight of social structures and reaffirm that class struggles articulate our present. In this essay, I would like to retrace the last few months in order to understand the political process from the wave of protests at the end of last year to the election results that gave victory to the teacher and unionist Pedro Castillo, who will soon be sworn in as president in the context of the bicentenary celebrations. I am driven by the idea that politics is the very fabric of history [la trama misma de la historia], as José Carlos Mariátegui said, and by paying attention to its weaving dynamic, we can begin to acknowledge what is at stake in the current situation. ${ }^{1}$

After the outbreak of the pandemic at the beginning of 2020 , which reached a very high death toll in the country and made visible the structural conditions that give the virus a class character, the intensity that political dynamics reached in the last few months did not seem foreseeable. ${ }^{2}$ For some months, the pandemic restrictions and the severity of the struggle for survival in the country seemed to slow

\footnotetext{
1 José Carlos Mariátegui, "Arte, revolución y decadencia”, in Amauta, n. 3, 1926. Available at: https:// www.marxists.org/espanol/mariateg/oc/el_artista_y_la_epoca/paginas/arte\%20revolucion\%20y\%20dec adencia.htm.

${ }_{2}^{2}$ See Jan Lust, "A Class Analysis of the Expansion of COVID-19 in Peru: The Case of Metropolitan Lima", Critical Sociology, 2021, Vol. 47 (4-5), 657-670.
}

Mijail Mitrovic

m.mitrovic@pucp.edu.pe

1 Pontificia Universidad Católica del Perú, Lima, Peru 
down any political mobilization. However, the succession of critical junctures has operated as a kind of negation of the so-called new normality that the pandemic installed in one of the most affected countries by the virus at the global level. In what follows, I will show how this fabric of history weaves the new into the knots of the old and what this implies for the country's immediate future.

\section{Empty time and political struggle}

A year ago, I argued that Peru had been largely conspicuous for its absence in the waves of protest that shook the region during 2019. We appeared to be that neoliberal "oasis" Sebastián Piñera imagined from prior to the outbreak that led to the ongoing constituent process in Chile. ${ }^{3}$ However, such a mirage of the oasis relocating to Peru was short-lived. The impoverishment unleashed by the pandemic contributed to undoing it, although is not the only factor that explains the political dynamics that I will present below. On a structural level, I argued that the pandemic had led the country to a break in the operability of what Walter Benjamin called "empty and homogeneous time", that time inherent to capitalist modernization where the illusions of progress obscure the conflicting coexistence of multiple historical temporalities.

After Alberto Fujimori's self-coup in 1992, the time of capitalist modernization in its neoliberal rhythm imposed itself by force, but it gained legitimacy after the fall of the dictatorship in 2000. That time became the ideological atmosphere of the bourgeoisies and middle classes throughout the country, and, while maintaining this spontaneous character, it made official politics seem to be resolved in the struggle between centrists and conservatives, all of them defenders of a basic liberal consensus. But the last few months show that this abstract time is leading to a struggle for historicity expressed in the choice between revolution and regression, akin to the global political shift generated by the capitalist crisis in the 1920s. Against bourgeois decadence and the ruin of capitalist civilization, said Mariátegui, emerge those who are willing to live dangerously and engage in an intense struggle for the orientation of history. ${ }^{4}$ How does this disjunction resurface in the present?

The removal of President Vizcarra from office by the Peruvian Congress at the beginning of November 2020 triggered a huge national mobilization against the government of Manuel Merino, a congressman from Acción Popular who earned widespread repudiation for orchestrating the coup against a president who enjoyed great popularity and for appointing ministers from the ranks of old, conservative politicians who emboldened police repression. Despite pressure in the media to discourage street mobilization because of the pandemic, the protests intensified in most

\footnotetext{
3 Mijail Mitrovic, "Empty Time (Peru under the pandemic)", Dialectical Anthropology, 44, 251-255, September 2020.

4 José Carlos Mariátegui, "Dos concepciones de la vida [1925]", in El alma matinal y otras estaciones del.
}

hombre de hoy, Lima: Empresa editora Amauta, 1970, pp. 13-18. 

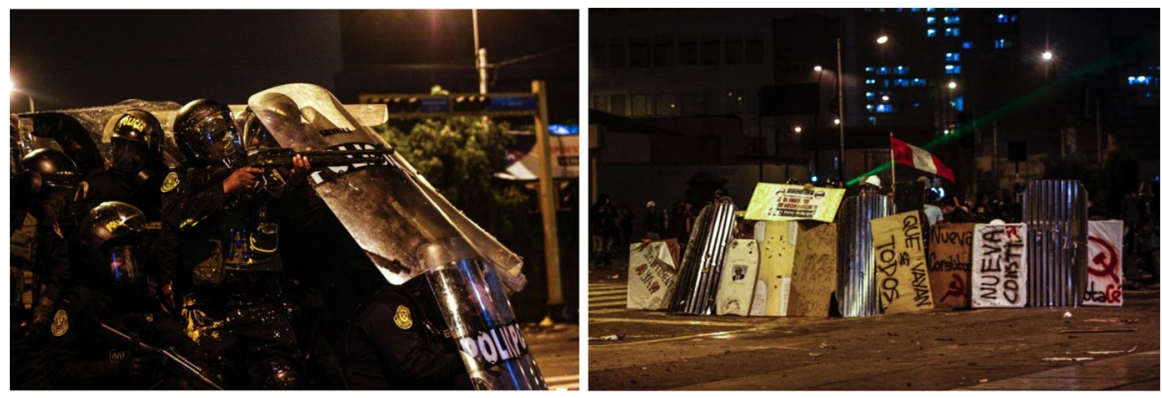

Fig. 1. 14 November 2020, Centre of Lima. Photos: Natalia Roncal

parts of the country, with demonstrations in unusual places and pots-and-pans in many cities. But repression also intensified, and on November 14, two young university students were killed by police in the centre of Lima. Shortly afterwards Merino's resignation, the Congress proclaimed the centrist Francisco Sagasti (Partido Morado) as the new transitional president, who sworn in offering to do justice for the dead and to vindicate the so-called Bicentennial generation - a hashtag that emerged in the protests and was quickly turned into state publicity.

The deaths of the two young men led to a dispute over public space that prefigured the following months: the memorials erected spontaneously by citizens were repeatedly razed to the ground by the pro-Fujimori group La Resistencia, a far-right shock troop that months later would boast of shouting "no to communism" with the fascist gesture of the raised right arm during the second round between Keiko Fujimori (Fuerza Popular) and Pedro Castillo (Perú Libre). But the victims of November also gave rise to a dispute within the political field articulated by the protests. While a group of young people demanded that their names be distanced from any heroic deeds for the "recovery of democracy" (which evoked the struggle against the Fujimori dictatorship in 2000), the left claimed that their deaths would not be in vain, as the current order had to be changed so that no one would ever again be killed for exercising their right to protest. The general election campaign was about to begin, and what had happened in those days of revolt needed to be canalized into the electoral contest.

The protests left remarkable scenes of contending forces, as shown in photographs taken from the field by Natalia Roncal [Fig. 1]. On one side, police prepared to shoot at the body; on the other, pickets of young people with helmets, rudimentary shields, and homemade tear-gas bomb disposal equipment barricade themselves in to resist the onslaught of repression. ${ }^{5}$ Hammers and sickles and slogans for a New Constitution appear alongside cries rejecting the entire political class, "que se vayan todos" [all of them must go]. From the protest arena, such dispersion was evident, as it was agglutinated by the rejection of Merino and widespread corruption. But from

\footnotetext{
5 A comprehensive visual record of the November protests can be found in the publication $11 / 20$, edited by Musuk Nolte and Sandra Rodríguez in KWY ediciones. Available at: https://tinyurl.com/KWY1120
} 
the heights of political analysis, it was said time and again that this was a "citizen" confluence in favour of democracy and that the protests did not mean a demand for radical transformations in the country.

Within a few weeks, protests broke out in various parts of the coastal strip dominated by agro-export industry, an economic sector that has enjoyed special regimes inherited from the dictatorship of the 1990s. Groups of young workers blocked roads demanding better working conditions - from being allowed to go to the toilet during the working day to full rights, better wages, etc. Unlike in November, this time, it did not take long for the hegemony's alarm bells to ring. The same media voices that before claimed the legitimate citizen character of the protests against Merino now stated that these young people from the agro-industrial proletariat were "violentistas" or "terrucos" (a Peruvian neologism coming from the war between Sendero Luminoso and the State, which stigmatizes as terrorists - terrucos - those who demand social justice). In other words, labour rights claims would not have, in this view, that sheen of legitimacy that liberals confer to what they consider to be democratic. Three young men under the age of 30 were killed in the December protests, but their deaths were not as high-profile as those of the young protesters in the capital.

Elsewhere I have offered a reading of that conjuncture. ${ }^{6}$ What is interesting here is to recognize that it made certain class limits visible in the political field: as long as the protest was not driven by demands seen as radical - such as the change of constitution - it would be well received, an example of a healthy democratic exercise; when the proletariat emerges to demand basic rights, however, the ghosts of terrorism are raised. It is true that in November, the demands for total transformation merged into a generic rejection of the prevailing order, but they did find an echo in the open struggle of the agrarian workers against their own exploitation, which, however, did not necessarily respond to a programme of radical transformation.

What is left over from that juncture? On the one hand, the feeling that the country was calling for urgent reforms, such as the restructuring of the national police, and for a certain minimal redistribution that would allow to pour water on the fire of the protests, gained ground among moderate sectors. On the other hand, despite the media blockade, the slogan of constitutional change made its way from November to the election campaign. Verónika Mendoza's social democracy and Pedro Castillo's socialist left mobilized this issue, although the latter remained off the radar of the mainstream press until shortly before the first round in April. In the following months, the demand for a New Constitution was rebranded as the proposal for a Constituent Assembly (in the social-democratic left) and a Popular Constituent Assembly (in the popular socialist left) and even some sectors of the right began to show less reluctance towards them, when it became clear that they had gained ground among the population.

Finally, the disengagement between the November and December protests unveiled an underground political scene for the official gaze, a potential popular

\footnotetext{
6 See the essay I wrote and published in January 2021, together with a photo essay by Musuk Nolte, in Mañana. Available at: https://www.xn--maana-pta.pe/post/restauracion-s-t-12-20-01-21
} 
arena that did not accept the mainstream blackmail to veer towards the centre, and which would accompany Castillo's “invisible" campaign together with the socialist party Perú Libre, founded by Marxist-leninist Vladimir Cerrón, a controversial figure on the left, who is facing legal proceedings for his time in the Junín regional government. This brings us to the second juncture.

\section{Class struggles and the ghosts of history}

Roque Benavides, former president of CONFIEP (National Confederation of Private Business Institutions), argued last year that the fall of the Berlin Wall in 1989 showed that today class struggle no longer exists. ${ }^{7}$ A certain echo of the "end of history" is still written in stone in the heads of the Peruvian ruling class. However, the electoral process that ended a month ago complicates this ideologeme. Still with Castillo off the radar, the media coverage of the campaign showed that the establishment regarded Mendoza's social democracy and his redistributive proposals as a "radical left" that should be folded to the centre. In some way, this pressure had an effect, and the campaign of Mendoza and Juntos Por el Perú - a coalition of left-wing parties and movements - gradually toned-down slogans such as "we are going to change everything", with which they launched their campaign in the midst of the November-December protests. However, as the effort to absorb the left into the hegemonic channels took effect, Castillo began to climb in the polls.

The candidate of the "invisible likes", as Doudtchitzky and Malaspina suggest, burst onto the official scene thanks to a campaign in which he toured the whole country in person. Regardless of the pandemic restrictions, Castillo bet on the irreplaceable aura that a face-to-face campaign generates, and the sanctions imposed on him more than once for gathering crowds on his trips around the country ended up strengthening him in the eyes of the people. This also triggered an intense deployment of a plebeian mediaspace - posters and flyers, radio, Facebook broadcasts of his rallies in various regional groups, etc. — which the mainstream press ignored until few weeks before the first round. ${ }^{8}$ They thought that, as a party based in the central highlands, Perú Libre would not have the capacity to articulate a campaign beyond the region where it has twice been in government. But reality proved the media's arrogance wrong, as well as that of the lefts who dismissed the possibility of

\footnotetext{
7 See Red de Comunicación Regional (2020), "Roque Benavides: empleo se logra con proyectos de inversión en marcha no con medidas para la tribuna”, June 15th, 2020. Available at: https://www.rcrpe ru.com/roque-benavides-empleo-se-logra-con-proyectos-de-inversion-en-marcha-no- con-medidas-parala-tribuna/

8 See Marcos Doudtchitzky, and Lucas Malaspina, "Pedro Castillo, el candidato de los 'likes invisibles",, in Nueva Sociedad, June 2021. Available at: https://nuso.org/articulo/facebook-not-dead-pedrocastillo-el- candidato-de-los-likes-invisibles/. Also, see Jimena Ledgard's early report about the role of social media in Pedro Castillo's campaign at https://restofworld.org/2021/peru-election-social-media/. Regarding the plebeian mediaspace, see Javier García Liendo, "Notas sobre el espacio mediático y la auralidad plebeya", Encuentros Latinoamericanos, vol. 3, n. 2, July/December 2019, pp. 31-51. Available at: https://ojs.fhce.edu.uy/index.php/enclat/article/view/466
} 
"profe" Castillo (diminutive for "profesor" [teacher]) making it to the second round — myself included.

On April 11, Castillo pulled several points ahead of Keiko Fujimori, who left behind her the far-right Rafael López Aliaga and the neoliberal guru Hernando de Soto, fragments of a right wing that wagered on dispersion. Mendoza, for her part, came in fifth place in the elections, behind Yohny Lescano, the Acción Popular candidate who for several months led the polls. Voter turnout was low, but the trend towards Castillo's victory was confirmed in the second round against Fujimori at the beginning of June, albeit by a slim margin and with all the media aligned behind the "no to communism" slogan, as part of the campaign of fear that the right brought into play with all its muscle. Billboards in the streets of Lima insisted on phrases such as "think of your children's future/No to communism", "communism generates misery and poverty", and allusions to the experiences of Cuba and Venezuela. The political debacle, however, was the less than $2 \%$ obtained by Julio Guzmán and the Partido Morado, an expression of the reformist centrism that local liberals have been dreaming of since Mario Vargas Llosa's defeat by Alberto Fujimori in $1990 .{ }^{9}$ With centrism shattered, it became clear that the political confrontation in the second round between left and right carried greater resonances of the confrontation between the hegemony of the bourgeoisie and the exhaustion of the proletariat in the country, even without a clearly defined counter-hegemonic project [Fig. 2].

Faced with the election results, Fujimori set in motion the Trump-like script of denouncing, without evidence, a fraud carried out not by the National Office of Electoral Processes, but by Peru Libre poll watchers. In order to save themselves from the judicial process currently underway, which calls for 30 years in prison for Keiko Fujimori and the highest spheres of Fuerza Popular, and with the media on their side — including firing journalists who did not align themselves with the owners of the press - they decided to denounce the fraud in order to cover the electoral process with a veil of suspicion (as the popular dictum says, "lie, lie, and something will remain"). The mainstream media shamelessly opted for fake news and a campaign of terruqueo. At the same time, and with the support of "top" law firms in Lima, Fuerza Popular sought the massive annulment of votes in rural where Fujimori was soundly defeated by Castillo. Despite its outright rejection by the National Jury of Elections, this shows the racist abysses of the Peruvian bourgeoisie, as they tried to erase the Quechua and Aymara peasantry of the southern Andean axis, historically linked to the left, from the electoral map. Finally, Vladimiro Montesinos, Alberto Fujimori's right-hand man in the 1990s, reappeared from the naval base where he is serving his sentence and sought to pay for the resolution of the vote challenges in favour of Fuerza Popular.

On another front, ranging from Mario Vargas Llosa and his son to former viceadmirals of the Peruvian Navy - the historic right wing of the armed forces there has been a call for a military coup to resolve this mess or for some international

\footnotetext{
${ }^{9}$ On the resonances of this centrist debacle in public discourse, see Daniel Luna and Mijail Mitrovic, "Usos de la república: la dimensión utópica", Trama, 24 July 2021. Available at: https://tramacritica.pe/ perspectivas/2021/07/24/usos-de-la-republica-la-dimension-utopica/
} 
Fig. 2 Poster circulated in Lima, May 2021

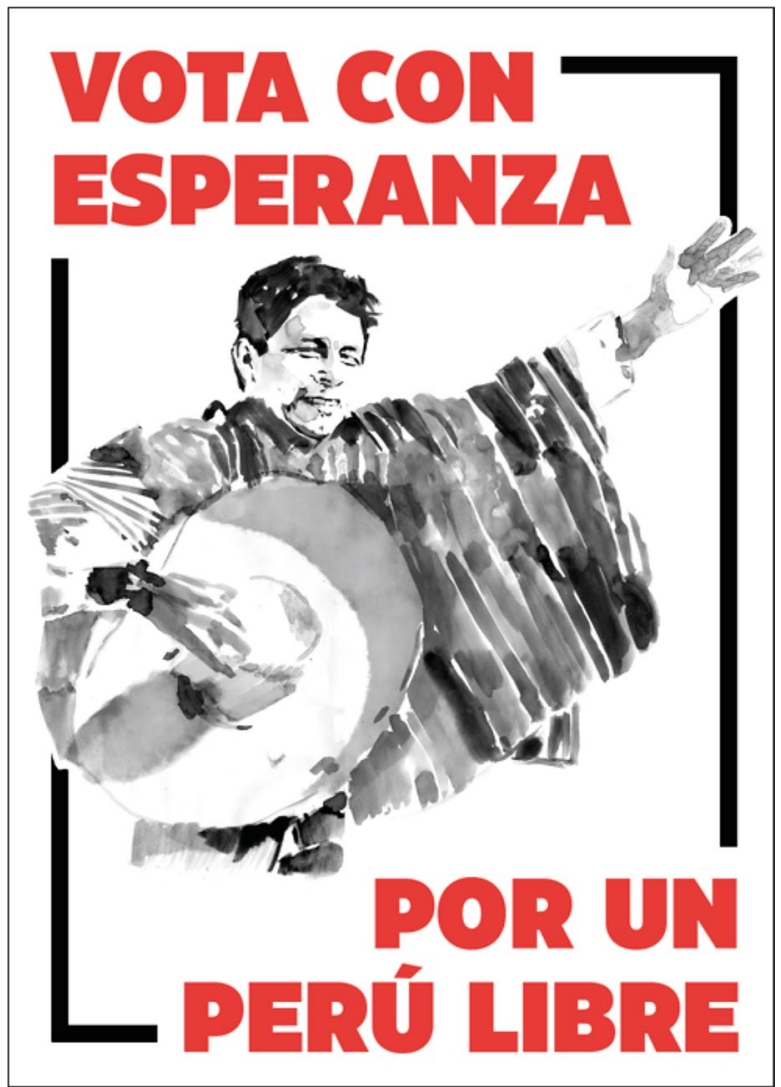

entity to intervene in the country. The latest scene in this unfruitful political operation was played out by a right-wing delegation that went to the doors of the OAS to request an audit of the electoral process, without realizing that the offices were closed due to the pandemic. Meanwhile, and already fully adapted to mobilization under pandemic conditions in the cities, supporters of Castillo and Perú Libre have taken to the streets in a festive mood - as photographer Ernesto Jiménez [Fig. 3] shows. The white bourgeoisie has done the same, although in a desperate mood: young people from Lima's richest districts wearing t-shirts that read "Better dead than red" [in English] meet with ex-military, libertarians, evangelical pastors, Opus Dei groups, and a portion of Lima's middle class to reject the alleged fraud and hope that someone will save them from the communist threat. A "new" right wing seems to be in the making. ${ }^{10}$ Contrary to what Roque Benavides thinks, that old slogan from around the 1950s (Better dead...) shows that, at least for his class, the Cold

\footnotetext{
${ }^{10}$ See Juan Carlos Ubilluz, "Sobre la especificidad de la derecha radical en América Latina y Perú. De Hitler y Mussolini a Rafael López Aliaga", Discursos del Sur, revista de teoría crítica en Ciencias Sociales, (7), 2021, 85-116.
} 


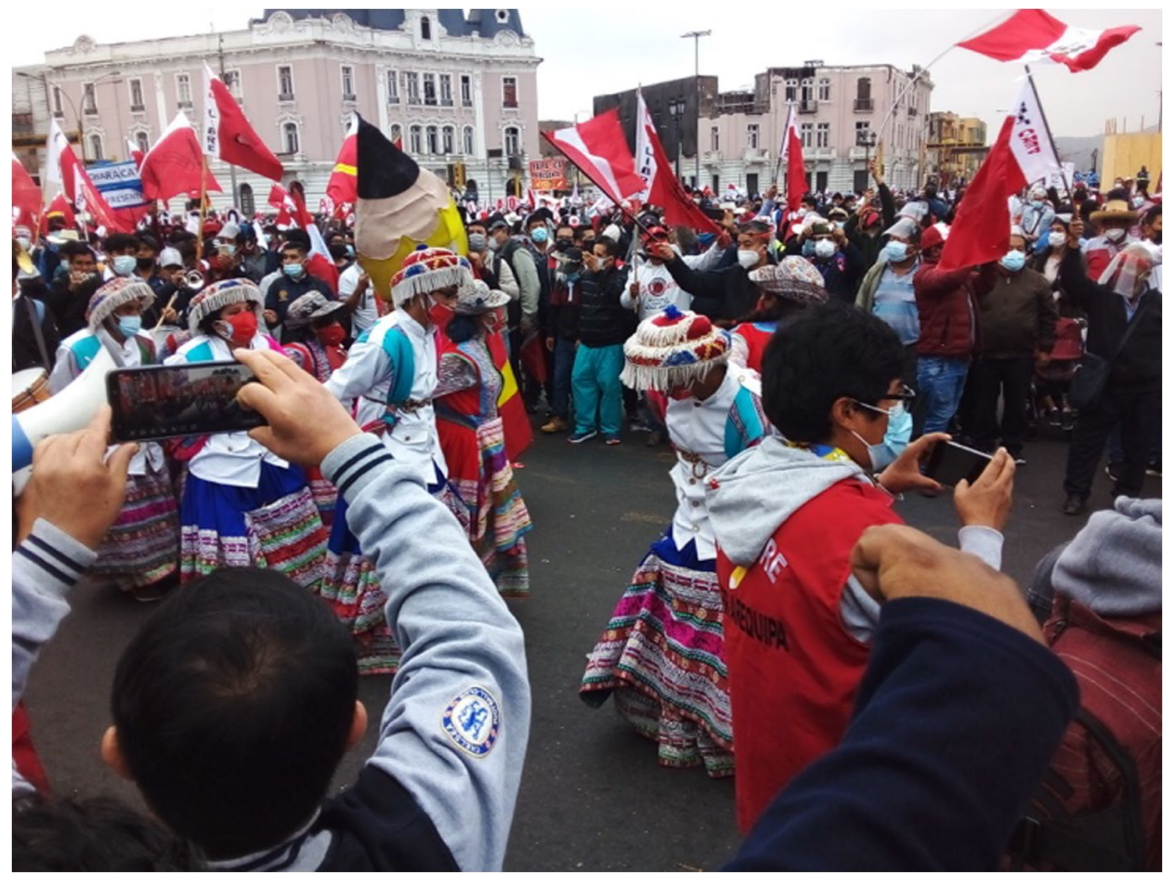

Fig. 3 Peru Libre supporters in Lima, 19 June 2021. Photo: Ernesto Jiménez

War never ended, although they have yet to recognize that class struggle has not ceased to exist either.

\section{A counter-hegemony still undefined}

It is remarkable that Fujimorismo has lost its old popular links gained under the dictatorship of the 1990s. The people articulated around Alberto Fujimori and his "double victory" in the economy and against subversion seem to have splintered, and Fujimorismo is now rooted in the urban bourgeoisie and the middle classes linked to them. Of course, this social base still allows it to gain some support among the working class, but its ideological proposal is today further away from the impoverished masses than from the middle class that still trusts the current order. Thus, neoliberalism as a programme no longer really has anything to offer to the masses, to those $2 / 3$ of the population who, in the words of Javier Monroe, have literally been left out of the nets of capital accumulation in the last three decades in the country. ${ }^{11}$ If neoliberal modernization was the last attempt at national integration that the ruling classes, in theory, had been betting on since the nineteenth century, we can say that, today, neoliberalism operates as a doctrine that seeks to prolong the

11 Javier Monroe, "Desacoplamiento estructural y crisis política total en el Perú", unpublished. 
social order installed in the 1990s, even if this requires open class confrontation. Its legitimacy is at rock bottom, as indicated by the anxiety that attacks right-wing politicians, the media, and an important group of the population in the face of Castillo's forthcoming proclamation. The delusions of insurgency of some libertarian influencers calling to arm themselves and the appearance of Spanish flags - like the Burgundy Cross - in the streets of Lima show that a sort of "class war of restoration" is gaining ground as an imagined alternative to the communist threat.

As for Fujimorismo as a movement, it should be said that today it is, first, the political arm of a criminal organization linked to drug trafficking that seeks impunity and then the conjunctural name of an oligarchy that does not want to lose its historical privileges, together with the fractions of the bourgeoisie that defend their right to unrestricted accumulation. And after that, Fujimorismo represents a middle class that, identified with its patrons, is captured by the fear of losing its lifestyle because of the left. All of this, as we have been working with Stephan Gruber, is articulated around a fear of the people that, although it has its roots in national history, deserves to be examined as the final inversion of the popular neoliberalism of the 1990s. Thus, Fujimorismo today is the passing name that the ruling class proposes as a political strategy, but embodies in the middle class, that "people of the capitalist oligarchies", in Badiou's words, where it finds a subject who will defend the patrons' skin with conviction. ${ }^{12}$ Keiko Fujimori's third electoral defeat augurs that the right-wing forces will bet on someone else in the coming years.

Now, the disparity in the electoral results of the left brings us back to the analysis of the class limits that came to the fore in the protests of late 2020, although it is now convenient to understand them as genuine class gaps. On the one hand, social democracy hesitated between representing those excluded from the prevailing order and being the voice of the middle classes who, impoverished by the current crisis, remain convinced of the validity of the hegemony that is now cracking. On the other hand, Perú Libre's socialism found in Castillo a figure that allowed him to represent a people who, although they do not necessarily define themselves as socialists, are tired of the political class and see the "profe" as someone who, from below, can bring the hope of transformation to fruition. If the former opted for Keynesian redistribution and a progressive agenda for the extension of social rights (LGBT community, care work, etc.), the latter proposed a socialist "popular economy with markets", similar to the MAS model in Bolivia, and an agenda of recognition centred on the working class inspired by the classics of Marxism and not by identity politics.

The debate within the left is complicated: for some, Castillo and Peru Libre are "conservative leftists" incapable of understanding contemporary progressivism, and Castillo, being a Catholic, would be willing to make a pact with the ultra-right on matters of gender equality. For others, this judgement comes from a left that responds to the dictates of international NGOs and USAID, incapable of understanding the real situation of the Peruvian working class and of standing firmly

\footnotetext{
12 Alain Badiou, "Twenty-Four Notes on the Uses of the Word 'People", translated by Jody Gladding, in Alain, Pierre Bourdieu, Judith Butler (et. al), What is a People? New York: Columbia University Press, 2016, pp. 21-31.
} 
against imperialism. Despite this ideological impasse, the left rallied around Castillo to confront Fujimori in the second round, and the very idea of a front against the right has opened a process of dialogue which, not without tensions, deserves to be deepened in order to build a unity capable of leading the popular field, where the possibility of a new counter-hegemonic project will be at stake. In the absence of a solid social movement backing the Castillo government, will it be able to articulate a national-popular subject that aspires to establish itself as a historical bloc (Gramsci) in the current context of the Bicentenary? Whether Castillo and Perú Libre will go down in history as the figures who organized a movement that is advancing towards the social control of historicity, according to the Touraine of the 1980s, will depend on it. ${ }^{13}$

On another level, I point to the need to (re)assume in the analysis that class struggle is the thread that weaves politics. Its denial has been commonplace in the consciousness of entrepreneurs, in the analysis that predominates in the public sphere, and in an academy that is stuck in the postmodern twists and turns of decades ago. It is a representational problem: one of the central ideological mechanisms of capitalism in history is the structural veiling of class struggles, the active work to obscure their existence and their confrontation as the primary historical dynamic. In our case, this veiling is the mechanism that insists on differentiating the "good" politics of citizenship that safeguard democratic institutions and the "bad" radical politics that block roads in rejection of exploitation. Indeed, if the former expresses the desires of the middle classes for stability and the latter is rooted in the proletariat, we are faced with two clearly differentiated agendas that express different and incompatible material situations.

But Castillo's electoral victory shows that between the two, there is a shared ground that advances towards "the objective of achieving recognition" which, in the words of Domenico Losurdo, characterizes the telos of class struggles in all their diversity. ${ }^{14}$ Peasants, workers, housewives, professionals, small and medium-sized entrepreneurs, students, etc., opted for Castillo because his figure represents a historical disengagement between state power and the ruling classes. Of course, one group did so reluctantly in order to defeat Fujimorismo, but it is important to understand that the class gaps that have blocked the reactivation of mass politics in Peru in recent decades seem to have narrowed a little. This brings the different material and subjective situations of those who wagered on Castillo closer to the minimum contents of class struggles in history: "on the economico-political level, it comprises the objective of altering the division of labour (internationally, inside the factory or family); on the politico-moral level, that of overcoming the dehumanizing and reifying processes which characterize capitalist society", notes Losurdo. Thus, the concealment and unconcealment of classes in struggle in recent months allows us

\footnotetext{
13 Alain Touraine, The Voice \& the Eye. An Analysis of social movements, translated by Alan Duff. Cambridge, NY, Melbourne: Cambridge University Press, Editions de la Maison Des Sciences De L'Homme, 1981, p. 77.

${ }^{14}$ Domenico Losurdo, Class Struggle. A political and philosophical history. New York: Palgrave Macmillan 2016, p. 83.
} 
Fig. 4 Coca-Cola advertisement for national holidays, El Sol, Cusco, Friday 28 July 1972

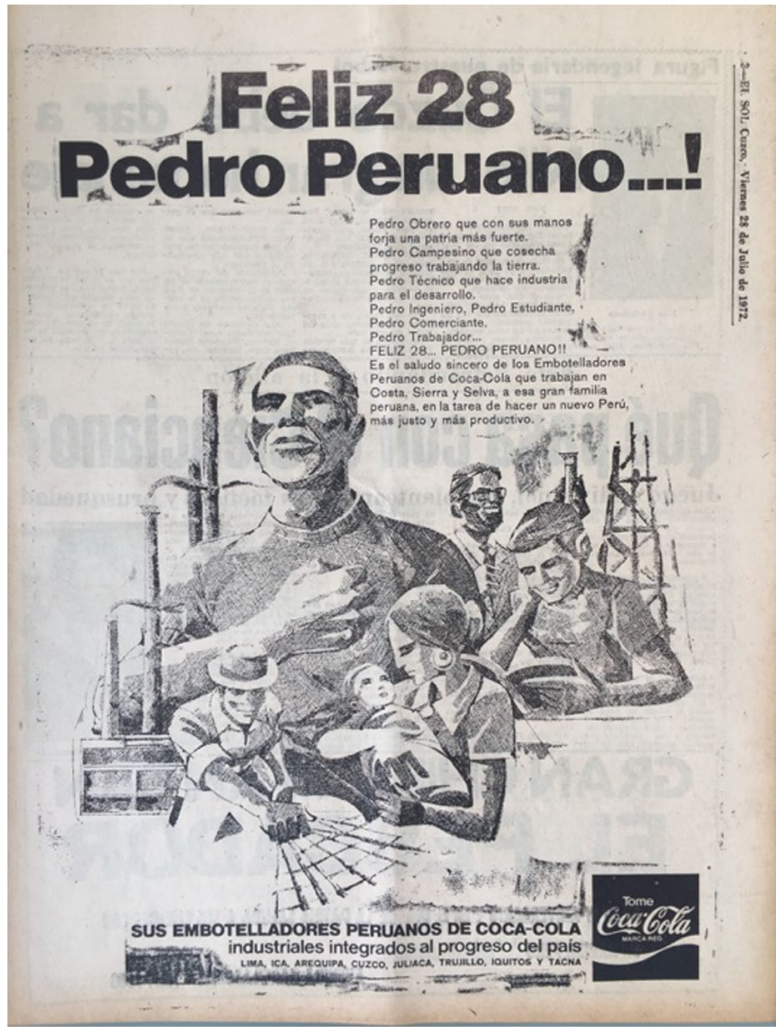

to understand the process of formation of a popular field or bloc, for the time being expressed as electoral articulation and defence of the vote, whose fragmentation or consistency will be the determining factor in the years to come.

\section{Pedro and the pencil (and a hat)}

Around the national holidays of 1972, amid the nationalist atmosphere under the progressive military regime led by Juan Velasco Alvarado, the Coca-Cola bottling company in Peru published an advertisement in the press [Fig. 4]. "Pedro peruano" [Peruvian Pedro], the personification of the common man, embodies here the worker, the peasant, the technician, the engineer, the student, etc. Women are not mentioned, although the drawing presents them as mothers. The text calls the people to "the task of making a new Peru, fairer and more productive". It is curious that, decades later, it is a new Pedro who comes to embody the first arrival of the people and the subaltern classes to the presidency of the republic.

As son of a hacienda worker in Cajamarca who was a beneficiary of Velasco's 1969 agrarian reform, Castillo embodies a historical inversion of power in Peru. But he does so not so much from the figures listed in the 1972 announcement, linked to the working class in the desarrollista horizon that would be later dismantled by 
Fig. 5 Peru Libre's pencil on the roadside, Cañete, Department of Lima. Photograph by the author

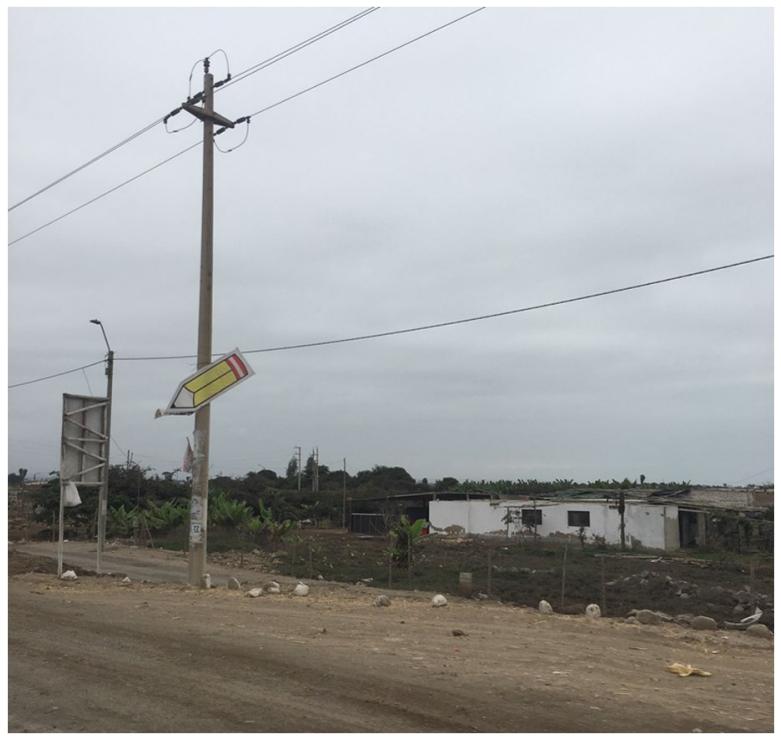

neoliberalism, but from his condition as a former rondero and above all as a schoolteacher, turned union leader in the teachers' struggles of 2017. It is also curious that the teachers' union, whose historical origins go back to its opposition to the Velasco regime in the early 1970 s, finds its most recent leader in a son of the agrarian reform, now projected as a potential national-popular political figure.

This new Pedro seemed to be an ideal character to give a face to the pencil, Peru Libre's logo that has marked territory during the campaign [Fig. 5]. The pencil stands out from the symbolism of the main political forces in recent Peru, usually linked to the names of candidates (Toledo, Ollanta, Keiko, PPK, etc.) or to the acronyms of political parties. Its graphic simplicity refers to the universe of education and writing and renews the visual imagery associated with the Peruvian left. The symbolic combo of the teacher and trade unionist, on the one hand, and the pencil, on the other, is complemented by the precise campaign slogan of Castillo and Perú Libre: "No more poor people in a rich country." Seen as a whole, it is not difficult to notice the enormous promise that surrounds the figure of Castillo (what he promises and what he personifies): it is about writing a new history in the country. However, once the campaign was over, Castillo took on the sombrero chotano - a peculiar hat, part of the peasant clothing of Cajamarca - as a fundamental part of his public persona, which adds an extra layer to the symbolic link between popular teacher and pencil described above, an issue we have been working on with Sandra Rodríguez. A symbol that the press has taken as a "disguise" and as a hiding place for the president, raising concerns about what would happen if he does not take it off when he should during official state acts, while Castillo rather manoeuvres with his hat and chooses when to take it off in front of the people, as he did during the announcement of the "Second Agrarian Reform" on October 3, the anniversary of Velasco's coup in 1968. 
Fig. 6 Peru Libre's pencil outside Sicuani, Cusco. Photo: Fernando Nureña Cruz

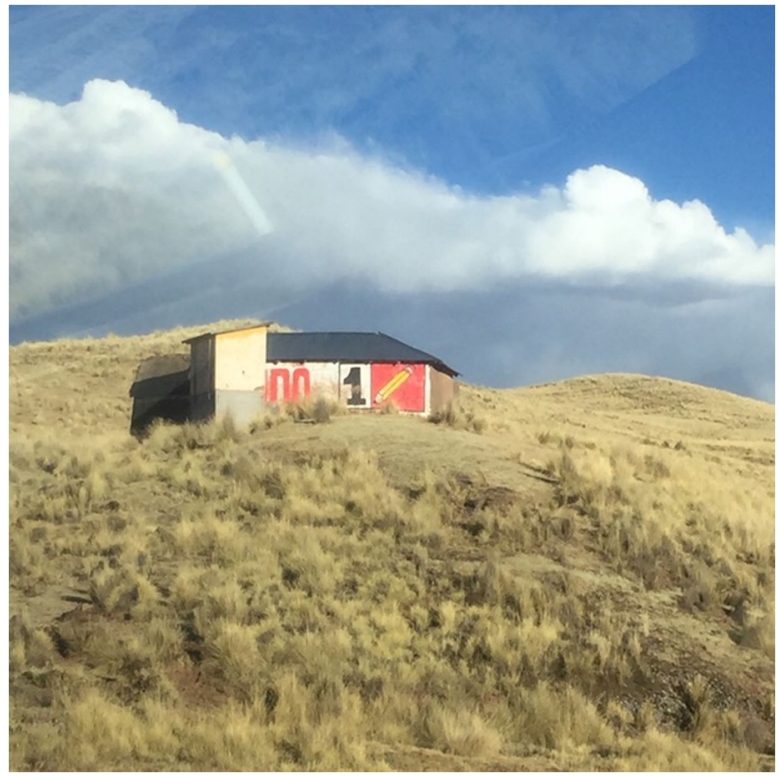

Alberto Flores Galindo argued, in a Thompsonian fashion, that class formations advance from the psychological level - feelings, attitudes, mentalities - towards a class culture crystallized in shared images of society and history, to finally shape class consciousness, the active knowledge of the previous levels and the political organization based on it. ${ }^{15}$ Against the neoliberal dismantling of class consciousness achieved in Peru throughout the twentieth century, the recent political process informs the beginning of its historical reconstitution, still on the basis of the first two levels proposed by the historian. The rejection of the "political class" and popular affects have found in Pedro and the pencil (and the chotano hat) new figure, different from those who offered to work for the people and betrayed their electoral promises immediately after assuming the presidency [Fig. 6].

Among the peasantry, teachers, housewives, students, and urban workers, it has often been heard that he is someone like us, and this identification shows its symbolic roots among the working classes, ready to be the people Castillo speaks of and which political analysts denounce as an old-fashioned entelechy. It remains to be seen whether these identifications will lead to a new "class-based" cycle in Peruvian history, to a moment when class cultures effectively crystallize as an operative consciousness in the face of political action. But, beyond the immediate fate of the new government, we are on fertile ground for the history of the subaltern classes in Peru to stop being "fragmented and episodic", as Gramsci thought, and manage to

\footnotetext{
15 Alberto Flores Galindo, Los mineros de la Cerro de Pasco 1900-1930: un intento de caracterización social y política. Lima: PUCP, Facultad de Ciencias Sociales, Taller Urbano-Industrial, 1973.
} 
become a permanent victory. ${ }^{16}$ The promise of historical vindication and reconstitution of the people has already been formulated.

\section{The democratic fact and its enemies}

The speed of events from the proclamation of Castillo in July to the present (October 2021) invites us to rethink the situation outlined above and begin to answer some of the questions raised. The government has been questioned at almost every move it has made. While criticism is necessary, the opposition insists that the government is "illegitimate", born of fraud, while the demolition campaign in the concentrated media continues. Ultimately, they do not accept the electoral defeat, and it should at least attract attention that today it is the openly authoritarian and conservative right that presents itself as the guarantor of democracy.

Alongside this, the demonstrations called by supposedly independent collectives, with posters and t-shirts financed by right-wing businessmen, also insist that we need a coup to fix this mess. The idea of a class war of restoration seems to have become a reality for a minority portion of society. Obviously, nothing good can come of this delusion. The decadent press has gone so far as to fantasize about Cerrón as the new "sword of Marxism”, including Chinese-style visual propaganda, and insist that Castillo is a puppet of Perú Libre. The international press also contributes to the attempt to separate Cerrón from the president. ${ }^{17}$ On the other side, the government seems to have retreated from what appeared to be an initial strategy of confrontation. The questionable departure of former guerrillero and sociologist Héctor Béjar from the Ministry of Foreign Affairs without being defended and his replacement by liberal Óscar Maúrtua should be enough to calm the anxieties of those who really fear communism.

It is still too early to know how far this anti-democratic bloc is willing to go, but it is likely that, after so many stumbles, it will try to do what many political analysts have been advising them to do: to bet on separating Perú Libre from power and trying to get Castillo to abandon his electoral promises, as Ollanta Humala did in 2011. As the first prime minister designated by the president, Perú Libre's congressman for Cusco Guido Bellido designated a cabinet that congregated figures from different political movements and some independents - several of them questionable, certainly. The recent replacement of Bellido for Mirtha Vásquez, lawyer and former president of Congress, which seems to show a certain separation between Castillo and Perú Libre, has pleased some right-wing sectors, but the demolition campaign will be quickly resumed.

\footnotetext{
16 Antonio Gramsci, "History of the Subaltern Classes: Methodological Criteria", translated by Quintin Hoare and Geoffrey Nowell Smith, in Selections from the Prison Notebooks. New York, London: International Publishers, Lawrence \& Wishart, 1971, pp. 54-55.

17 See https://www.bloomberg.com/news/articles/2021-08-23/havana-trained-marxist-pushesperu-s-new-president-to-the-left?fbclid=IwAR21wdcVIUwgzNJq_nQPpOabVLmQ7Pj_E2axB QENXYaG2UWEfLwQnA081M4
} 
This move has complicated the government's ability to keep the left in tense unity, which will end up fragmenting if Castillo gives in on the Popular Constituent Assembly, his main banner during the electoral process. Apart from that, the pandemic situation itself has put health, education, and the economy as immediate priorities, and the question is how to solve them properly. That is the real first test of the new government, but it would help if, as they say, they "let them work". In that sense, the redefining of the aid bonds allocation mechanism to alleviate the economic crisis and the increased pace of vaccinations are tangible indicators of the government's management capacity. We are still waiting for the "third wave", but the prospects seem better than what we have experienced in the last year and a half.

The initial difficulties of the new government might invite me to retreat from the enthusiasm that animated the preceding sections of this essay, much of it written before Castillo's proclamation, but that would ignore what these last few months have set in motion at every level in Peru. The historic promise and opportunity that Castillo embodies - beyond himself, as I said - continue to generate anxieties and fears that seem unlikely to be relieved until the opposition manages to block them altogether or until the government succeeds in unleashing a popular mobilization that will be an effective support against the right-wing onslaught. Tony Wood has already pointed to the political difficulties facing the new government and the likelihood of a "prolonged and turbulent interregnum" between democratic renewal and neoliberal restoration. ${ }^{18}$ We will see how long the interregnum extends, but I would like to conclude by saying something about the current ideological dispute.

As dangerous as it is to insist too much on fantasies is to undo them altogether, and today, with the proliferation of ghosts of the past and restorative desires, there is no choice but to confront them on several levels. First, through a broad debate on our history that helps to discern which events are really a thing of the past. As former Foreign Minister Béjar rightly said, today the Shining Path "no longer exists, but it is still present in the press", where it is openly used to delegitimize any demand for transformation. ${ }^{19}$ In the face of terruqueo, it is worth examining in depth the history of terrorism in the country, as Cecilia Méndez has advanced in a recent essay, where she analyses the historical process of semantic inversion from the use of terrorism to denounce state violence to its dominant identification with political violence against the state, already during the twentieth century. ${ }^{20}$

Secondly, the recent electoral process calls for the left to recognize and defend the democratic institutionality that has allowed Castillo's victory, despite criticisms of how democracy has been operating since the fall of Fujimori in 2000. Curiously, today many self-styled democrats are the first to promote the idea that the winning party should not govern, which invites the questioning of several commonplaces in

\footnotetext{
18 Tony Wood, “Castillo’s Path”, Sidecar, 30 August 2021. See https://newleftreview.org/sidecar/posts/ castillos-path

19 See Sengo Pérez, "Este es el comienzo de un golpe blando. Entrevista a Héctor Béjar", Brecha, 20 de agosto 2021. Disponible en: https://brecha.com.uy/este-es-el-comienzo-de-un-golpe-blando/

${ }^{20}$ Cecilia Méndez, "The Paths of Terrorism in Peru. Nineteenth to Twenty-First Centuries", in Richard English (ed.), The Cambridge History of Terrorism, 2021, pp. 420-452.
} 
the dominant political analysis (the non-existence of parties, in the first place). If they demanded the left to accept the democratic order, they should do the same and leave behind this selective use of the very notion of democracy.

Finally, this ideological dispute is above all about affirming other ideals that are capable of counteracting the regressive forces that are currently threatening democracy. These ideals are currently in the process of being reformulated, subjected to the tests of reality, of being in government, of facing a tough opposition, etc. It seems that the most complicated thing today is to affirm socialist ideals in the midst of disinformation, fear, and lies. Perhaps the most important challenge for the socialist left in Peru today is precisely to affirm itself, to get out of the critical and reactive position to which we have become accustomed, and to demonstrate in practice that these ideals, planned for decades as abstract ideas, pursue welfare, equality, recognition, etc. Opening the way for this urgent socialist affirmation will be enough to speak of a true historic change that will redefine the Peruvian political arena. In the best scenario, we will see progress towards substantive democracy, on which other more far-reaching aspirations can be built.

Acknowledgements I'd like to thank Matheus Calderón for helping me translate this essay. Raúl Álvarez and Daniel Luna provided valuable comments on the first draft.

Publisher's note Springer Nature remains neutral with regard to jurisdictional claims in published maps and institutional affiliations. 